\title{
REVIEW TERHADAP LIMA LITERATUR RENCANA BISNIS
}

\author{
Ahmadi Usman ${ }^{1}$ \\ ${ }^{1}$ Dosen Jurusan Administrasi Niaga, Politeknik Negeri Ujung Pandang
}

ahmadiusman@poliupg.ac.id

\begin{abstract}
ABSTRAK
Artikel ini akan mereview lima artikel yang ditulis by Davidson (2015), Delmar (2015), Delmar and Shane (2003), Honing and Karlsson (2004), dan Honig and Samuelsson (2014) menyangkut pendapat yang berbeda mengenai penggunaan rencana bisnis. Metode yang digunakan dalam artikel ini adalah sebuah analisis konten dengan menggunakan metode deskripsi. Hasil penelitian menunjukkan bahwa kelima artikel rencana bisnis yang dibahas memiliki sudut pandang yang berbeda mengenai penggunaan metodologi. Walaupun ada yang setuju dan tidak setuju terhadap penggunan dokumen rencana bisnis dalam artikel ini, kami menyarankan bahwa sangat penting untuk menunjuk seorang ahli dalam penelitian rencana bisnis untuk mengurangi kemungkinan perdebatan terus-menerus dalam topik rencana bisnis.
\end{abstract}

Kata kunci: Artikel, rencana bisnis

\section{ABSTRACT}

This article will review five articles written by Davidson (2015), Delmar (2015), Delmar and Shane (2003), Honing and Karlsson (2004), and Honig and Samuelsson (2014) regarding different claims of the use of business plan. The method used in this article is a content analysis by using descriptive method. The result of this article shows that these five articles have different viewpoints toward the use of methodology. Although there are pro and cons viewpoints of using business plan, in this paper, we suggest that it is important to appoint an editor in business plan research to reduce the possibility of upcoming debate in this topic.

Keywords: Article, business plan

\section{PENDAHULUAN}

Kewirausahaan telah diajarkan secara luas di berbagai institusi pendidikan dan telah menjadi mata kuliah yang wajib di tingkat universitas di seluruh dunia. Salah satu dari banyak topik yang dipelajari dalam mata kuliah kewirausahaan adalah rencana bisnis. Sebuah rencana bisnis didefinisikan sebagai dokumen formal yang ditulis oleh pengusaha yang menggambarkan seluruh aspek dari bisnis secara komprehensif (Guta 2014; Lange et al. 2007; Rijal, Chowdhury \& Lanichhane 2010; Schaper \& Volery 2004). Sebuah pertanyaan dapat diangkat apakah menulis rencana bisnis merupakan keharusan atau tidak untuk para pengusaha. Saat ini, banyak penelitian telah dilakukan untuk menjawab pentingnya penggunaan rencana bisnis. Pada kenyataannya, penelitian rencana bisnis berakhir kedalam debat yang mana dapat dibagi kedalam peneliti yang mendukung pandangan rencana bisnis dan sejumlah ahli yang menentang pandangan rencana bisnis. Beberapa contoh peneliti yang memiliki sudut pandang yang berbeda diantaranya Davidson (2015); Delmar (2015); Delmar and Shane (2003); Honing and Karlsson (2004); Honig and Samuelsson (2014). Penelitian ini akan mereview lima artikel untuk pendapat yang dibuat oleh para peneliti menyangkut penggunaan rencana bisnis untuk para pengusaha pemula. Dalam mereview artikel ini, penulis menggunanakan content analysis dengan mengunakan metode deskripsi. Setelah mereview kelima artikel ini, penulis dengan kuat berpendapat bahwa rencana bisnis harus ditulis oleh para pengusaha pemula karena memiliki 
lebih banyak manfaat positif daripada manfaat negatif. Selain itu, penelitian ini akan mendiskusikan beberapa keterbatasan dari penemuan peneliti menyangkut penelitian rencana bisnis.

\section{PEMBAHASAN}

Salah satu peneliti yang melakukan penelitian tentang rencana bisnis adalah Delmar and Shane (2003) yang disingkat dengan "D\&S". Temuan dari Delmar and Shane (2003) menunjukkan bahwa rencana bisnis secara positif berkaitan dengan aktivitas pengelolaan usaha, pengembangan produk, dan mengurangi kemungkinan dari pembubaran usaha. Delmar and Shane menggunakan studi longitudional dengan jumlah sampel sebanyak 223 usaha baru yang mana diperoleh dari studi panel versi Swedia tentang dinamika pengusaha. Kekuatan penelitian Delmar and Shane terletak pada implikasinya yang mana mengembangkan sebuah teori baru, mengatasi masalah metodologi, dan memberikan pengetahuan kepada dunia praktisi. Argumen ini didukung oleh Bartunek, Rynes and Ireland (2006) yang mana berpendapat bahwa kriteria yang baik dalam sebuah artikel adalah memberikan implikasi yang penting dan bersifat praktis dan membangun sebuah teori yang baru. Sebaliknya, kelemahan dari artikel Delmar and Shane ditunjukkan oleh penggunaan sampel. Diketahui bahwa Delmar and Shane tidak secara jelas menjelaskan untuk jenis usaha baru yang digunakannya sehingga sampel dari usaha yang digunakan menjadi heterogen yang mana pada gilirannya akan menciptakan data bias. Akan tetapi, meskipun kemungkinan data bias dapat terjadi karena persoalan usaha yang heterogen, Delmar and Shane (2003) dan Delmar (2015) berpendapat bahwa penggunaan dari model regresi efek yang fix dapat mengatasi masalah isu data bias. Sebaliknya dengan D\&S, Davidson (2004) dalam bukunya yang berjudul Research Entrepreneurship, menyarankan bahwa sangat penting untuk mengelompokkan sebuah kategori yang homogen untuk sebuah perusahaan atau bisnis yang akan digunakan sebagai sampel penelitian berdasarkan kelas ukuran dan industri untuk menghindari data bias.

Itu juga menarik untuk mereview artikel yang ditulis oleh Honig and Karlsson (2004) yang disingkat sebagai "H\&K" yang menggunakan data set yang sama dengan artikel milik D\&S, namun berbeda dala hal penggunaan metodologi. Hasil penelitian H\&K menunjukkan bahwa tingkat profitabilitas usaha baru tidak dipengaruhi oleh rencana bisnis dan kemampuan bertahan hidup tampaknya tidak berhubungan rengan menulis rencana bisnis. Hasil penelitian H\&K juga menemukan bahwa faktor paksaaan adalah variabel yang menyebabkan seorang pengusaha baru menulis rencana bisnis. Dalam mengumpulkan data mereka, H\&K menggunakan sebuah kontak telpon untuk mewawancarai 396 pengusaha muda daripada menggunakan teknik wawancara tatap muka. Meskipun keuntungan wawancara telepon dari segi kecepatan respon dan biaya rendah (Miller 1995; Sturges \& Hanrahan 2004; Veal 2005), penggunaan wawancara telpon dapat menciptakan respon yang salah karena jawaban yang kurang akurat sehingga itu dapat mempengaruhi kualitas data (Assael \& Keon 1982). Pada saat yang sama, artikel H\&K tidak secara jelas menjelaskan apakah variabel coercive, mimetic, dan jenomative diiukur dengan skala ordinal dan nominal. Lebih jauh, kekuatan dari artikel ini terletak pada tujuan penelitian yang kuat dan hipotesis didukung dengan teori dan jurnal-jurnal yang relevan.

Artikel berikutnya yang akan direview adalah sebuah penelitian yang dilakukan oleh Honig and Samuelsson (2014) yang disingkat dengan "H\&S" dengan menggunakan replikasi data dan metode perluasan. Tujuan dari artikel $H \& S$ adalah untuk menambah tujuh tahun tambahan untuk periode penelitian dan menggunakan variabel yang sama seperti yang diteliti oleh D\&S and H\&K. Pada kenyataannya, temuan dari artikel H\&S secara keseluruhan sama dengan temuan penelitian artikel $\mathrm{H} \& \mathrm{~K}$ bahwa rencana bisnis tidak secara positif berkorelasi 
dengan tingkat hidup sebuah usaha. Akan tetapi, Honig and Samuelsson (2014) tidak memberikan alasan spesifik untuk menjelaskan penyebab penemuan yang mirip dengan artikel milik D\&S dan penemuan ini hanya berfokus kepada hasil statistik yang tidak signifikan. Lebih jauh, H\&S juga mereplikasi penelitian mirip D\&S yang mana menemukan beberapa kelemahan artikel D\&S dari segi data internal yang hilang, masalah kausalitas, dan kegagalan dari regresi efek tetap untuk mengatasi sensor yang tertinggal. Temuan dari Honig and Samuelsson (2014) menggunakan variabel D\&S menunjukkan bahwa rencana bisnis tidak mempengaruhi pengembangan sebuah bisnis dan hanya beberapa usaha yang maju yang menulis perencanaan strategis untuk perencanaan internal mereka. Akan tetapi, dalam kaitannya dengan artikel H\&S di tahun 2014, Delmar (2015) menolak untuk menerima sebagian besar pendapat yang dibuat oleh Honig and Samuelsson (2014) dengan menyediakan pendapat tandingan. Kemungkinan kesalahpahaman H\&S disebabkan oleh kekurangan dari deskripsi mentodologi yang ditampilkan oleh artikel D\&S (Davidsson 2015).

Perselisihan antara peneliti menyangkut replikasi data dan perluasan dalam penelitian kewirausahaan telah memperoleh perhatian yang serius dari peneliti lainnya. Davidson (2015) merupakan salah satu dari peneliti kewirausahaan yang berusaha untuk memberikan pencerahan tentang debat diantara $H \& S$ and $D \& S$. Untuk menyeimbangkan argumentasi diantara H\&S dan D\&S dan memberikan pemahaman kepada peneliti lain dalam bidang kewirausahaan, Davidson (2015) berusaha menggambarkan beberapa kelemahan artikel H\&S and D\&S. Akibatnya, hal ini dapat dipelajari dari kedua artikel ini bahwa tidak mudah untuk melakukan sebuah penelitian (Davidson, 2015) dimana para peneliti harus menghormati hasil temuan yang berbeda dari peneliti lain. Walaupun temuan yang berbeda merupakan hal yang lazim, sangat disarankan untuk menunjuk penilai eksternal yang memiliki keahlian mendalam dalam bidang metodologi replikasi data dan perluasan. Argumen ini didukung oleh Evanschitzky (2007) yang merekomendasikan bahwa kehadiran mentor replikasi dan perluasan data dapat mendorong jumlah penelitian replikasi.

\section{KESIMPULAN}

Setelah mereview lima artikel yang berbeda tentang penggunaan rencana bisnis sebagaimana yang dijelaskan di atas, penulis berpendapat bahwa pengusaha pemula sangat direkomendasikan untuk menulis sebuah rencana bisnis karena beberapa alasan. Tak dapat disangkal, pengusaha pemula kekurangan pengetahuan dan menghadapi lebih banyak ketidakpastian dalam proses penciptaan usaha baru. Untuk isu-isu ini, mereka harus melakukan perencanaan sebelum membuat usaha yang dituangkan kedalam sebuah dokumen yang dikenal dengan rencana bisnis dengan melakukan penelitian, proyeksi persiapan keuangan, dan mengurangi risiko. Pengusaha pemula yang sudah menulis sebuah rencana bisnis jauh lebih nyaman dan percaya diri untuk memulai usaha barunya (Liao \& Gartner 2006). Ketika usaha yang baru sudah berkembang, pengusaha akan membutuhkan lebih banyak modal dimana mereka akan menggunakan dokumen rencana bisnis sebagai alat promosi untuk mendapatkan pendanaan dari luar (Lange et al. 2007, p. 237; Rijal, Chowdhury \& Lamichhane 2010).

\section{UCAPAN TERIMA KASIH}

Penulis mengucapkan banyak terima kasih kepada kolega penulis yang telah membantu mencarikan artikel yang relevan sesuai dengan judul artikel yang diangkat. Penulis juga mengucapkan kepada editor yang telah memeriksa kesalahan penulisan dalam artikel ini. 


\section{DAFTAR PUSTAKA}

Assael, H., \& Keon, J. (1982). Nonsampling vs. sampling errors in survey research. Journal of Marketing, 46, 114-123.

Bartunek, J. M., Rynes, S. L., \& Ireland, R. D. (2006). What makes management research interesting, and why does it matter? Academy of Management Journal, 49(1), 9-15.

Bygrave, W. D., Lange, J., Mollov, A., Pearlmutter, M., \& Singh, S. (2007). Pre-startup formal business plans and post-startup performance: A study of 116 new ventures. Venture Capital Journal, 9(4), 1-20.

Chowdhury, L. N., Lamichhane, P., \& Rijal, A. (2010). Study on the Relationship between Business Planning and SMEs or Individual Entrepreneurship.

Davidsson, P. (2004). Researching entrepreneurship. Springer.

Davidsson, P. (2015). Data replication and extension: A commentary. Journal of Business Venturing Insights, 3, 12-15.

Delmar, Frédéric. (2015). A response to Honig and Samuelsson (2014). Journal of Business Venturing Insights, 3, 1-4.

Delmar, Frederic, \& Shane, S. (2003). Does business planning facilitate the development of new ventures? Strategic Management Journal, 24(12), 1165-1185.

Evanschitzky, H., Baumgarth, C., Hubbard, R., \& Armstrong, J. S. (2007). Replication research's disturbing trend. Journal of Business Research, 60(4), 411-415.

Guţă, A. J. (2014). The role and importance of the business plan in starting and running a business opportunity. Annals of the University of Petroşani. Economics, 14, 119-126.

Honig, B., \& Karlsson, T. (2004). Institutional forces and the written business plan. Journal of Management, 30(1), 29-48.

Honig, B., \& Samuelsson, M. (2014). Data replication and extension: A study of business planning and venture-level performance. Journal of Business Venturing Insights, 1, 18 25 .

Liao, J., \& Gartner, W. B. (2006). The effects of pre-venture plan timing and perceived environmental uncertainty on the persistence of emerging firms. Small Business Economics, 27(1), 23-40.

Miller, C. (1995). In-depth interviewing by telephone: Some practical considerations. Evaluation \& Research in Education, 9(1), 29-38.

Sturges, J. E., \& Hanrahan, K. J. (2004). Comparing telephone and face-to-face qualitative interviewing: a research note. Qualitative Research, 4(1), 107-118.

Veal, A. J. (2005). Business Research Methods: A Managerial Approach.: Malaysia. Pearson.

Volery, T., \& Schaper, M. (2007). Entrepreneurship and small business: a Pacific Rim perspective. John Wiley \& Sons Australia, Ltd. 